Ralph Ellison in Progress 
This page intentionally left blank 


\title{
Ralph Ellison in Progress
}

From Invisible Man to

Three Days Before the Shooting...

\author{
ADAM BRADLEY
}

\author{
Yale \\ UNIVERSITY \\ PRESS
}

New Haven and London 
Published with assistance from the foundation established in memory of Philip Hamilton McMillan of the Class of 1894, Yale College.

Copyright $\odot 2010$ by Adam Bradley.

All texts by Ralph Ellison $\odot$ The Ralph and Fanny Ellison Charitable Trust.

All rights reserved.

This book may not be reproduced, in whole or in part, including illustrations, in any form (beyond that copying permitted by Sections 107 and 108 of the U.S. Copyright Law and except by reviewers for the public press), without written permission from the publishers.

Set in Minion type by Integrated Publishing Solutions, Grand Rapids, Michigan.

Printed in the United States of America by Maple-Vail.

Library of Congress Cataloging-in-Publication Data

Bradley, Adam.

Ralph Ellison in progress : from Invisible man to Three days before the shooting ... / Adam Bradley.

p. $\mathrm{cm}$.

Includes bibliographical references and index.

ISBN 978-0-300-14713-1 (alk. paper)

1. Ellison, Ralph-Technique. 2. Ellison, Ralph-Manuscripts.

3. Ellison, Ralph. Invisible man. 4. Ellison, Ralph. Three days before the shooting ... I. Title.

PS3555.L625Z57 2010

$813^{\prime} .54-\mathrm{dc} 22 \quad 2009036607$

A catalogue record for this book is available from the British Library.

This paper meets the requirements of ANSI/NISO Z39.48-1992 (Permanence of Paper). 
To John F. Callahan

On the Higher Frequencies 
This page intentionally left blank 